\title{
Utilização da rede social facebook em sala de aula
}

\author{
El uso de la red social Facebook en clase
}

\author{
${ }^{1}$ Aline Moura Domingues; ${ }^{2}$ Dr. Maurício Aires Vieira \\ 1 alinemouradomingues@gmail.com, Universidade Federal do Pampa; ${ }^{2}$ mau.vieira@ gmail.com, \\ Universidade Federal do Pampa.
}

\begin{abstract}
Resumo
O presente trabalho surge a partir de um questionamento realizado por um aluno do $6^{\circ}$ ano do ensino fundamental em sala de aula. Como sabemos, as tecnologias da informação e da comunicação (TIC) estão cada vez mais presentes em nossas vidas, inclusive em sala de aula. Para sustentar nossos argumentos, diante dessa situação apresentada, utilizaremos Pretto e Assis (2008) para referenciar sobre cultura digital, Recuerdo (2014) que aborda sobre rede social facebook e Pretto (2010) com relação às redes colaborativas. Este trabalho tem a seguinte estrutura, cultura digital, rede social facebook, postura do professor diante do assunto exposto, o porquê de seu espanto e como essa ferramenta pode auxiliar no seu planejamento docente, além das considerações.
\end{abstract}

\section{Considerações Iniciais}

O presente trabalho surge a partir de um questionamento realizado por um aluno do $6^{\circ}$ ano do ensino fundamental em sala de aula. O mesmo perguntou a sua professora de ciências o porquê de não utilizar a ferramenta facebook em suas aulas, como resposta a mesma disse que não é um instrumento de aprendizagem.

Como sabemos, as tecnologias da informação e da comunicação (TIC) estão cada vez mais presentes em nossas vidas, inclusive em sala de aula. Para sustentar nossos argumentos, diante dessa situação apresentada, utilizaremos Pretto e Assis (2008) para referenciar sobre cultura digital, Recuerdo (2014) que aborda sobre rede social facebook e Pretto (2010) com relação às redes colaborativas.

Este trabalho tem a seguinte estrutura, cultura digital, rede social facebook, postura do professor diante do assunto exposto, o porquê de seu espanto e como essa ferramenta pode auxiliar no seu planejamento docente, além das considerações.

\section{Cultura Digital}

A partir do século XXI muitas transformações aconteceram, junto a isso, surgiram alguns problemas por conta crescimento das TIC. Os sujeitos começaram a se apropriar dessa tecnologia "estejamos ou não conectados a computadores e à internet, tendo em vista a interdependência em várias áreas e setores sociais e econômicos [...]” ( Pretto e Assis (2008:75).

Presentemente podemos expor que essa cultura digital está cada vez maior e os sujeitos estão conectados a diferentes dispositivos. Este espaço digital possibilita a relação social entre os seres, além de criação e produção de diferentes materiais e inúmeras outras atividades possíveis de se realizar nesse espaço.

Deve se ter claro que, ter acesso às tecnologias é essencial, mas esse acesso carece de qualificação, pensando se utilizaremos desta em sala de aula. Segundo o autor Pretto e Assis (2008:81) apresenta que: 
“[...] as tecnologias mais simples, como livros impressos, ou de outras mais avançadas, como os computadores em rede, produzindo novas realidades, exige o estabelecimento de novas conexões que as situem diante dos complexos problemas enfrentados pela educação. [...]" (PRETTO e ASSIS, 2008:81)

Os adolescentes foram os que se apropriaram e transformaram as tecnologias. Atualmente, não só o jovem, mas em todas as idades estão utilizando as TIC em seu dia a dia. Segundo Pretto (2010:310) "essas máquinas não estão a penas a serviço do homem, mas que com ele interagem, formando um conjunto homem-maquina pleno de significado".

Hoje em dia a escola esta se desenvolvendo no sentido de ampliar e multiplicar as culturas, "promovendo interação entre sujeitos, entre si e com a tecnologia" (Pretto,2010:313) que possibilita o deslocamento para outros conhecimentos.

A internet em si ainda é considerada em algumas escolas como um elemento estranho, um dos motivos pode ser pelo fato do jovem estar conectado a todo o momento e o professor se sente acuado por não dominá-lo. No próximo tópico abordaremos sobre a rede social facebook, além da postura do professor frente a essa ferramenta em sala de aula.

\section{Rede social facebook}

Essa ferramenta facebook serve para "construir o espaço social no cotidiano dos atores, gerando práticas que ressignificam seus usos" (Recuero, 2014:114). Algumas possibilidades desta ferramenta esta a conversação, utilizadas por ferramentas textuais.

Os atores podem publicar imagens, vídeos, músicas, textos, entre outros, utilizar as ferramentas de curtir, compartilhar e comentar. Além disso, há possibilidade de bate-papo com uma ou várias pessoas, também é possível criar um grupo (fechado, secreto, aberto) para desenvolver diferentes atividades e entre outros inúmeros recursos disponíveis nessa ferramenta. .

Quando o aluno do $6^{\circ}$ ano pergunta para sua professora de ciências o porquê do não uso da ferramenta facebook em suas aulas e a mesma responde que este instrumento não é de aprendizagem. Podemos pensar em duas situações, primeiro a professora não ter uma conta e por esse motivo não sabe utilizar a ferramenta e segundo é possuir uma conta, mas não dominar a ferramenta. Hoje em dia, o professor necessita qualificação nas TIC, para que saiba utilizar diversas ferramentas em sala de aula, inclusive as que público de sua atuação utiliza.

"As tecnologias digitais e a internet, em particular, são tratadas como meras ferramentas auxiliares dos processos educacionais" Pretto (2010:307). Nesse sentido, não significa excluir ou deixar de utilizar o livro, caderno e quadro, mas que repensem suas práticas docentes, utilizando as TIC para aprimorar e desenvolver atividades interativas e significativas.

Essa ferramenta facebook pode contribuir para qualquer área do conhecimento, refletindo sobre ciências, a professora pode desenvolver diversas atividades como: criar seu grupo da disciplina, para poder compartilhar diversos materiais da disciplina, os alunos poderão publicar seus trabalhos (não somente no grupo), mas mostrar para diversas pessoas o que estão realizando em sala de aula.

Este instrumento, como diversos outros, faz com que a aula se estenda que não fique o reconhecimento de seu trabalho e as tarefas realizadas pelos alunos somente na sala de aula. Esses materiais podem ser visualizados por diversas pessoas, podendo ser curtido, comentado e compartilhado com outras pessoas.

Há autores que abordam sobre o mau uso dessas tecnologias, no sentido de reproduzir e utilizar expressões abreviadas, pois nessa ferramenta e em outras para a comunicação acontecer de forma rápida são abreviadas e utilizam expressões mais diretas, não tirando o sentido da oração, mas com ortografia incorreta. 


\section{Considerações finais}

Para concluir, podemos relatar que a postura da professora de ciência era o não conhecimento da ferramenta, ou seja, não saber explorar. Por esse motivo, argumentou que essa ferramenta não servia para aprendizagem dos mesmos. Sendo assim, podemos dizer que essa ferramenta contribui para o ensino em sala de aula. O professor deve estar sempre se apropriando para saber como utilizá-la no ambiente escolar.

O sentido de apropriação é de se aperfeiçoar nas TIC, é necessário qualificação para ter conhecimento de diversas ferramentas, como também de objetos de aprendizagem, estes que são específicos para serem trabalhados em sala de aula.

\section{Referências}

PRETTO, NL., and ASSIS, A. Ensaio: cultura digital e educação: redes já! In PRETTO, NL., and SILVEIRA, SA., orgs. Além das redes de colaboração: internet, diversidade cultural e tecnologias do poder. [online]. Salvador: EDUFBA, 2008. pp. 75-83.

PRETTO, Nelson. Redes colaborativas, ética hacker e educação. Educação em revista [online]. 2010, vol.26, n.3, pp. 305-316.

RECUERDO, Raquel. Curtir, compartilhar, comentar: trabalho de face, conversação e redes sociais no Facebook - Revista Verso e Reverso (Online), v.28, n. 68, 2014/2. 